\title{
Antibacterial Activity and Physical Properties of Edible Chitosan Films Exposed to Low-pressure Plasma
}

\author{
Natalia Ulbin-Figlewicz • Anna Zimoch-Korzycka • \\ Andrzej Jarmoluk
}

Received: 3 April 2014 / Accepted: 20 July 2014 / Published online: 2 August 2014

(C) The Author(s) 2014. This article is published with open access at Springerlink.com

\begin{abstract}
The challenge for food industry is developing gentle processes concept, which will prevent food spoilage and leave a food natural, minimally processed, fresh-like and safe. A new technique of food preservation could be usage of combined methods of green process, such as cold gas plasma with bioactive substances, and protective coatings. The aim of this study was to determine the antibacterial activity of chitosan films incorporated with lysozyme exposed to helium plasma treatment as well as evaluate their physical properties. The edible films have been prepared basing on low molecular weight chitosan by casting from lactic acid solution with water solution of lysozyme in three various concentrations $(0,0.5$ and $1 \%$ ). Dried films were then modified by exposition on cold helium plasma treatment for 0,5 and $10 \mathrm{~min}$. Obtained films were tested against growth of Listeria monocytogenes, Yersinia enterocolitica and Pseudomonas fluorescens. In order to characterize chitosan-based films, their mechanical properties, theromogravimetric analysis (TGA), dynamic mechanical thermal analysis (DMTA), contact angle measurement, water vapour permeability (WVP) and scanning electron microscopy (SEM) were evaluated. The films with $1 \%$ lysozyme incorporation enhanced the inhibition efficiency of chitosanbased films against gram-positive (L. monocytogenes) and gram-negative (P. fluorescens) bacteria, where reduction zones were 42.5 and $69.8 \mathrm{~mm}$, respectively. Besides that, hydrolytic changes of chitosan chain caused by lysozyme activity were confirmed by TGA and DMTA. Contact angles and WVP of tested films were not significantly affected by helium plasma exposition, nor lysozyme dosage. Hydrophilic natures of chitosan-based films were confirmed by both tests.
\end{abstract}

N. Ulbin-Figlewicz $(\bowtie) \cdot A$. Zimoch-Korzycka $\cdot$ A. Jarmoluk Department of Animal Products Technology and Quality

Management, Wrocław University of Environmental and Life

Sciences, ul. Chełmońskiego 37/41, 51-630 Wrocław, Poland

e-mail: nataliaulbin@tlen.pl
Microscopy image of cross-section structure was smooth and continuous due to lysozyme addition in film composition. Application of chitosan films incorporated with lysozyme and low-pressure plasma treatment could be used as innovative preservation method in a wide range of food products.

Key words Antibacterial activity $\cdot$ Lysozyme $\cdot$ Low-pressure plasma $\cdot$ Chitosan film $\cdot$ Meat industry

\section{Introduction}

In recent years, the application of edible films and coatings in food industry has raised attention of many authors (Moreira et al. 2011; Ye et al. 2008; Yuceer and Caner 2013). It is claimed that they can reduce physical changes in fresh products as well as extend the shelf life of food due to incorporation of antimicrobial components (Skurtys et al. 2010). The most common natural compound is chitosan. This polysaccharide is produced by de- $N$-acetylation of chitin. Due to its unique functional and biomedical properties, industrial application of chitosan is wide and is ranging from pharmaceutical and cosmetic products, textile and paper industry to water engineering and plant protection (Dutta et al. 2004). Biodegradation and compatibility with other substances forming edible coatings make chitosan a very valuable polymer for application in food packaging.

Microbial spoilage leading to deterioration of meat quality and loss of weight through surface evaporation are the most important issues in meat industry (Sofos 1994). As a consequence, they contribute to financial loss and increase health hazards. Considering expectation of consumers and manufacturer, implementation of a new method of meat decontamination is a challenge. Therefore, non-thermal, green technologies are being looked for by the researchers. Cold plasma is known as one of this novel method and its effectiveness in 
sterilization process was confirmed (Moisan et al. 2002). Some advantages of low-pressure plasma such as the large treatable area, even distribution in vacuum chamber, uniformly treatment and low temperature of process are especially beneficial in meat industry.

Previous study confirmed inhibitory effect of helium plasma treatment, which inspired us to investigate combination of cold plasma and edible films. Research studies are divided into two stages. The aim of the first one (present) is to determine the antibacterial activity of chitosan films incorporated with lysozyme exposed to helium plasma treatment and evaluation of their physical properties. Effectiveness of studied methods will be carried out on food products in the second stage.

\section{Material and Methods}

\section{Preparation of Chitosan Films}

Low molecular weight chitosan (DD 75-85\%) was purchased from Sigma-Aldrich Co. LLC (USA). Chitosan stock solution was prepared in diluted lactic acid and was stirred overnight at room temperature. Glycerol (PPH Stanlab, Poland) was added as a plasticizer. Lysozyme (Ovopol, Poland) stock solution was prepared by dissolving in distilled water. The solutions were mixed in the appropriate proportions of final concentrations as shown in Table 1. The mixture was centrifuged at $5,000 \mathrm{~g}$ for $10 \mathrm{~min}$ at $20^{\circ} \mathrm{C}$, and $80 \mathrm{ml}$ of it was spread evenly onto an $80 \times 200$-mm glass plate covered with Teflon foil and cleaned with ethanol. The plates were dried at $4{ }^{\circ} \mathrm{C}$ and $60 \%$ $\mathrm{RH}$ for $96 \mathrm{~h}$ in Binder KBF-LOC 240 climate chamber.

\section{Low-pressure Plasma Treatment}

The study was conducted with samples not exposed to helium plasma and samples treated with cold plasma for 5 and $10 \mathrm{~min}$

Table 1 Experimental design

\begin{tabular}{|c|c|c|c|c|c|}
\hline \multirow[t]{2}{*}{ Variants } & \multicolumn{2}{|c|}{ Variability factors } & \multicolumn{3}{|c|}{ Constant factors } \\
\hline & $\begin{array}{l}\text { Plasma } \\
\text { exposure } \\
(\mathrm{min})\end{array}$ & $\begin{array}{l}\text { Lysozyme } \\
(\%)\end{array}$ & $\begin{array}{l}\text { Chitosan } \\
(\%)\end{array}$ & Glycerol (\%) & $\begin{array}{l}\text { Lactic } \\
\text { acid } \\
(\%)\end{array}$ \\
\hline POL0 & 0 & 0 & \multirow[t]{9}{*}{1} & \multirow{9}{*}{$\begin{array}{l}25 \text { (of dry weight } \\
\text { of used polymers) }\end{array}$} & \multirow[t]{9}{*}{0.5} \\
\hline P5L0 & 5 & 0 & & & \\
\hline P10L0 & 10 & 0 & & & \\
\hline P0L0.5 & 0 & 0.5 & & & \\
\hline P5L0.5 & 5 & 0.5 & & & \\
\hline P10L0.5 & 10 & 0.5 & & & \\
\hline P0L1 & 0 & 1.0 & & & \\
\hline P5L1 & 5 & 1.0 & & & \\
\hline P10L1 & 10 & 1.0 & & & \\
\hline
\end{tabular}

at final pressure $20 \mathrm{kPa}$. Cold plasma was produced by high voltage discharge in a vacuum chamber (100 Pa) using the prototype-pulsed plasma reactor Ertec Poland (Fig. 1). Electrical impulses were generated using a pulse generator operating at frequencies around $70 \mathrm{kHz}$ and $1.2 \mathrm{kVA}$ power, adjustable in the range 0.5 to $20 \mathrm{kV} \mathrm{AC}$, with minimum pulse repetition time of $0.5 \mathrm{~s}$.

\section{Antibacterial Activity}

Plate diffusion test was used to determine the antibacterial activity of edible film. Listeria monocytogenes PCM 2606, Yersinia enterocolitica PCM 2080 and Pseudomonas fluorescens PCM 1994 were obtained from the culture collections of Institute of Immunology and Experimental Therapy, Polish Academy of Sciences. P. fluorescens and $Y$. enterocolitica inoculums were prepared by growing cells in enriched broth (BTL, Poland) for $24 \mathrm{~h}$ at $37{ }^{\circ} \mathrm{C}$ and L. monocytogenes in brain-heart infusion broth (Merck Millipore, USA) at $30{ }^{\circ} \mathrm{C}$. Optical density of the bacterial culture was measured in a Ray Leigh UV 1800 spectrophotometer at $\lambda=550 \mathrm{~nm}$. The inoculum containing $10^{6} \mathrm{CFU} / \mathrm{ml}$ was evenly spread on agar plates. Uniform 30-mm-diameter discs were cut from the prepared chitosan film with a scalpel, and one film disc was placed in the centre of the inoculated petri dish. The plates were incubated at $37{ }^{\circ} \mathrm{C}$ for $24 \mathrm{~h}$ (Y. enterocolitica and P. fluorescens) and at $30{ }^{\circ} \mathrm{C}$ for $48 \mathrm{~h}$ (L. monocytogenes). The diameter of the inhibition zone $(\mathrm{mm})$ was measured using the GIMP 2 program.

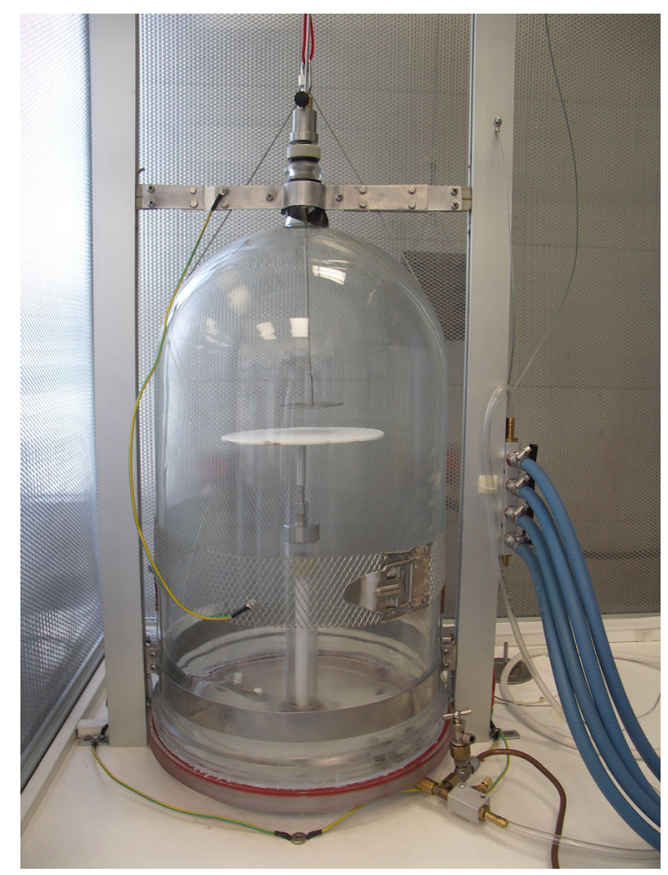

Fig. 1 Cold plasma generator 
Mechanical Properties

ASTM D 882.1995 method was used for measuring the tensile strength (TS) and elongation at break (EB). Designation of selected mechanical parameters was performed using a Material Testing Machines Zwick/Roell Z010. Films were stretched using a crosshead speed of $125 \mathrm{~mm} / \mathrm{min}$. TS is defined as stress, which is measured as used force $(\mathrm{N})$ per tested unit area $\left(\mathrm{mm}^{2}\right)$. EB is defined as the ratio between changed length and initial length after breakage of the test specimen.

\section{Thermogravimetric Analysis}

The thermal gravimetric analysis (TGA) was conducted to measure the thermal stability of chitosan films on Thermogravimetric Analyser Hi-Res TGA 2950 (TA Instruments). The analyses were made at the temperature varying from 0 to $300^{\circ} \mathrm{C}$ in an inert nitrogen atmosphere with flow of $60 \mathrm{ml} / \mathrm{min}$ and rate warming of $10^{\circ} \mathrm{C} / \mathrm{min}$. The testing area of strips was $25 \mathrm{~mm}^{2}$.

\section{Dynamic Mechanical Thermal Analysis}

Dynamic mechanical thermal analysis (DMTA) was performed by using Rheometric Scientific DMTA Mk III. The analyses were conducted by keeping the frequency constant $(1 \mathrm{~Hz})$ and varying the temperature at a heating rate of $2{ }^{\circ} \mathrm{C} / \mathrm{min}$ from -80 to $50{ }^{\circ} \mathrm{C}$.

\section{Contact Angle Measurements}

Contact angles of wettability were measured in an air using a contact angle analyser (Surface Electro Optics). A film sample $\left(2 \mathrm{~cm}^{2}\right)$ was put on a movable sample stage and levelled horizontally; then, a drop of about $6 \mu \mathrm{l}$ of distilled water was placed on the surface of the film using a microsyringe.

\section{Water Vapour Permeability}

Water vapour permeability of films was determinated gravimetrically using ASTM E-96 method. The cups were filled with $100 \mathrm{~cm}^{3}$ of distilled water each. A sample was placed in between the cup and the ring cover of each cup. Then, they were stored in temperature-controlled cabinet at $4{ }^{\circ} \mathrm{C}$ and $60 \% \mathrm{RH}$. Cups were weighed every hour for $6 \mathrm{~h}$. Water vapour transmission rate (WVTP) was estimated using the following equation:

$\mathrm{WVTR}=G /(t \times A)$

where $G$ is the change in weight (g), $t$ is the time (h) and $A$ is the test area $\left(\mathrm{m}^{2}\right)$.
Water vapour permeability (WVP) was calculated as

$\mathrm{WVP}=(\mathrm{WVPR} \times T) / \Delta P$

where $T$ is the thickness of the test specimen (mm) and $\Delta P$ is the partial pressure difference of the water vapour across the film.

\section{Scanning Electron Microscopy}

Microstructure of surface and cross section of chitosan films was evaluated using EVO LS15 ZEISS Scanning Electron Microscopy. The samples under study were first sputtered with gold during $150 \mathrm{~s}$ using a sputter coater Scancoat 6 (Edwards, London). Each coated sample was examined using a voltage of $20 \mathrm{kV}$.

\section{Statistical Analysis}

The experiments were replicated three times and analyses were made in triplicate for each sample (three independent experiments analysed in triplicate). The effects of two independent categorical variables such as time of exposure and concentration of lysozyme were evaluated. Data were analysed by two-way factor analysis of variance (ANOVA) using Statistica 9 (StatSoft, Poland) (Miller and Haden 2006). Differences between mean values were identified by Duncan test with a confidence level at $p<0.05$.

\section{Results and Discussion}

Antibacterial Activity

The inhibitory effect of edible films against all tested bacteria was observed (Tables 1 and 2). Increased concentration of lysozyme up to $1 \%$ caused significantly larger inhibition

Table 2 Antibacterial activity of chitosan films (main effects)

\begin{tabular}{cccc}
\hline Main effect & \multicolumn{3}{l}{ Inhibition zone $(\mathrm{mm})$} \\
\cline { 2 - 4 } & P.fluorescens & L.monocytogenes & Y.enterocolitica \\
\hline Lysozyme (\%) & & \\
0 & $61.7 \pm 5.4^{\mathrm{a}}$ & $36.2 \pm 1.58^{\mathrm{a}}$ & $40.0 \pm 3.20^{\mathrm{a}}$ \\
0.5 & $59.8 \pm 2.56^{\mathrm{a}}$ & $42.6 \pm 2.10^{\mathrm{b}}$ & $40.2 \pm 3.16^{\mathrm{a}}$ \\
1.0 & $69.8 \pm 3.80^{\mathrm{b}}$ & $42.5 \pm 2.22^{\mathrm{b}}$ & $40.5 \pm 3.41^{\mathrm{a}}$ \\
Plasma exposure (min) & & \\
0 & $62.7 \pm 8.02^{\mathrm{a}}$ & $39.7 \pm 3.19^{\mathrm{a}}$ & $39.1 \pm 2.57^{\mathrm{a}}$ \\
5 & $63.6 \pm 4.33^{\mathrm{a}}$ & $40.6 \pm 4.16^{\mathrm{a}}$ & $40.7 \pm 3.03^{\mathrm{a}}$ \\
10 & $64.9 \pm 5.26^{\mathrm{a}}$ & $40.8 \pm 5.74^{\mathrm{a}}$ & $40.9 \pm 3.43^{\mathrm{a}}$ \\
\hline
\end{tabular}

Values with different letters $(\mathrm{a}-\mathrm{b})$ within the same column differ significantly $(p<0.05)$ 
Table 3 Antibacterial activity of chitosan films (interaction effects)

Interaction effects Inhibition zone (mm)

\begin{tabular}{lccl}
\cline { 2 - 4 } & P.fluorescens & L.monocytogenes & Y.enterocolitica \\
\hline P0L0 & $54.3 \pm 0.58^{\mathrm{a}}$ & $35.9 \pm 1.60^{\mathrm{a}}$ & $38.0 \pm 1.90^{\mathrm{a}}$ \\
P5L0 & $62.0 \pm 2.52^{\mathrm{b}}$ & $36.7 \pm 1.76^{\mathrm{a}}$ & $40.5 \pm 2.76^{\mathrm{a}, \mathrm{b}}$ \\
P10L0 & $68.8 \pm 2.89^{\mathrm{c}}$ & $35.9 \pm 1.54^{\mathrm{a}}$ & $42.5 \pm 2.71^{\mathrm{b}}$ \\
P0L0.5 & $58.8 \pm 1.73^{\mathrm{a}, \mathrm{b}}$ & $41.40 .87^{\mathrm{b}}$ & $39.5 \pm 2.24^{\mathrm{a}, \mathrm{b}}$ \\
P5L0.5 & $61.3 \pm 2.89^{\mathrm{b}}$ & $42.1 \pm 2.07^{\mathrm{b}}$ & $41.5 \pm 2.16^{\mathrm{a}, \mathrm{b}}$ \\
P10L0.5 & $59.3 \pm 4.04^{\mathrm{b}}$ & $44.1 \pm 2.30^{\mathrm{b}}$ & $39.5 \pm 2.38^{\mathrm{a}, \mathrm{b}}$ \\
P0L1 & $75.0 \pm 3.06^{\mathrm{c}}$ & $41.9 \pm 1.95^{\mathrm{b}}$ & $40.6 \pm 3.00^{\mathrm{a}, \mathrm{b}}$ \\
P5L1 & $67.5 \pm 1.15^{\mathrm{c}}$ & $43.2 \pm 2.29^{\mathrm{b}}$ & $40.0 \pm 2.95^{\mathrm{a}, \mathrm{b}}$ \\
P10L1 & $66.8 \pm 1.00^{\mathrm{c}}$ & $42.5 \pm 2.62^{\mathrm{b}}$ & $40.6 \pm 3.33^{\mathrm{a}, \mathrm{b}}$ \\
\hline
\end{tabular}

Values with different letters $(a-c)$ within the same column differ significantly $(p<0.05)$

zones of L. monocytogenes and P. fluorescens and was 42.5 and $69.8 \mathrm{~mm}$, respectively. Hughey and Johnson (1987) reported that lysozyme effectively inhibits the growth of grampositive bacteria including L. monocytogenes. The inactivation is caused by splitting the bonds between $\mathrm{N}$ acetylmuramic acid and $N$-acetylglucosamine of the peptidoglycan in cell walls. Because of outer membrane in gramnegative bacteria, which precludes the access to lytic enzymes, they are usually insensitive to lysozyme (Salazar and Asenjo 2007). However, in combination with chitosan and lactic acid, inhibitory effect could be achieved. Several reports have shown the antimicrobial effect of chitosan against a wide range of bacteria (Benhabiles et al. 2012; Chung et al. 2004; Elsabee and Abdou 2013). Chitooligosaccharydes prepared by hydrolysis are more efficient in inhibiting of various strains of bacteria compared to chitin and chitosan (Benhabiles et al. 2012). Therefore, the use of chitosan and lysozyme as components of edible films is advantageous due to their higher antibacterial activity. Spectrum of bacteria sensitive to lysozyme action can be extended by means of modifications. Changes in the conformation of enzyme molecules cause increasing antibacterial activity in relation to gram-negative bacteria (Cegielska-Radziejewska et al. 2008).

No significant differences in inhibitory zone between time of plasma exposure were observed. Plasma species responsible for sterilization interact with bacterial cells. Thus, the inactivation of microbes is possible, when they are directly exposed to cold plasma. Earlier studies confirmed inhibitory effect of low-pressure plasma against surface microflora of meat (Ulbin-Figlewicz et al. 2013). According to hurdle technology, combination of several treatments is more efficient in food preservation (Leistner and Gould 2002). Therefore, the usage of cold plasma in combination with natural preservatives such as edible coatings could improve microbial stability and/or quality of food. Studies on meat-coated edible film and directly exposed to helium plasma treatment need to be further investigated.

Table 4 Mechanical properties of chitosan films

\begin{tabular}{|c|c|c|c|c|c|}
\hline \multicolumn{4}{|l|}{ Main effects } & \multicolumn{2}{|c|}{ Interaction effects } \\
\hline Plasma exposure (min) & $\mathrm{TS}(\mathrm{MPa})$ & Lysozyme (\%) & TS (MPa) & $\mathrm{P} \times \mathrm{L}$ & TS (MPa) \\
\hline \multirow[t]{3}{*}{0} & $13.21 \pm 6.02^{\mathrm{a}}$ & 0 & $16.19 \pm 5.95^{\mathrm{a}}$ & $0 \times 0$ & $16.71 \pm 6.38^{\mathrm{a}}$ \\
\hline & & & & $5 \times 0$ & $15.22 \pm 5.57^{\mathrm{a}}$ \\
\hline & & & & $10 \times 0$ & $16.74 \pm 5.98^{\mathrm{a}}$ \\
\hline \multirow[t]{3}{*}{5} & $12.91 \pm 5.19^{\mathrm{a}}$ & 0.5 & $12.08 \pm 4.70^{\mathrm{b}}$ & $0 \times 0.5$ & $10.85 \pm 5.55^{\mathrm{b}, \mathrm{c}}$ \\
\hline & & & & $5 \times 0.5$ & $12.14 \pm 4.92^{\mathrm{b}, \mathrm{c}}$ \\
\hline & & & & $10 \times 0.5$ & $14.18 \pm 3.14^{\mathrm{b}, \mathrm{c}}$ \\
\hline \multirow[t]{3}{*}{10} & $13.36 \pm 4.90^{\mathrm{a}}$ & 1 & $10.92 \pm 3.40^{\mathrm{b}}$ & $0 \times 1$ & $10.99 \pm 3.03^{\mathrm{c}, \mathrm{d}}$ \\
\hline & & & & $5 \times 1$ & $10.96 \pm 3.81^{\mathrm{c}, \mathrm{d}}$ \\
\hline & & & & $10 \times 1$ & $9.70 \pm 2.22^{\mathrm{d}}$ \\
\hline Plasma exposure (min) & $\mathrm{EB}(\%)$ & Lysozyme (\%) & EB $(\%)$ & $\mathrm{P} \times \mathrm{L}$ & EB $(\%)$ \\
\hline \multirow[t]{3}{*}{0} & $7.91 \pm 2.91^{\mathrm{a}}$ & 0 & $9.69 \pm 4.37^{\mathrm{a}}$ & $0 \times 0$ & $10.01 \pm 2.92^{\mathrm{a}, \mathrm{b}}$ \\
\hline & & & & $5 \times 0$ & $10.03 \pm 4.34^{\mathrm{a}, \mathrm{b}}$ \\
\hline & & & & $10 \times 0$ & $11.19 \pm 5.3^{\mathrm{a}}$ \\
\hline \multirow[t]{3}{*}{5} & $8.38 \pm 3.63^{\mathrm{a}}$ & 0.5 & $8.08 \pm 2.76^{\mathrm{b}}$ & $0 \times 0.5$ & $8.04 \pm 3.03^{\mathrm{b}, \mathrm{c}, \mathrm{c}}$ \\
\hline & & & & $5 \times 0.5$ & $8.37 \pm 3.37^{\mathrm{b}, \mathrm{c}, \mathrm{c}}$ \\
\hline & & & & $10 \times 0.5$ & $7.46 \pm 2.26^{\mathrm{c}, \mathrm{d}}$ \\
\hline \multirow[t]{3}{*}{10} & $8.40 \pm 3.84^{\mathrm{a}}$ & 1 & $6.65 \pm 1.90^{\mathrm{c}}$ & $0 \times 1$ & $7.11 \pm 1.79^{\mathrm{c}, \mathrm{d}}$ \\
\hline & & & & $5 \times 1$ & $6.05 \pm 1.80^{\mathrm{c}, \mathrm{d}}$ \\
\hline & & & & $10 \times 1$ & $6.88 \pm 2.0^{\mathrm{c}, \mathrm{d}}$ \\
\hline
\end{tabular}

Values with different letters $(a-d)$ within the same column differ significantly $(p<0.05)$ 
Table 5 Results of thermogravimetric analysis

\begin{tabular}{|c|c|c|c|c|c|}
\hline \multirow[t]{2}{*}{ Sample } & \multicolumn{2}{|l|}{ First stage } & \multicolumn{2}{|l|}{ Second stage } & \multirow[t]{2}{*}{ Weight remaining after $300^{\circ} \mathrm{C}$} \\
\hline & $\mathrm{T}\left({ }^{\circ} \mathrm{C}\right)$ & Weight loss $(\%)$ & $\mathrm{T}\left({ }^{\circ} \mathrm{C}\right)$ & Weight loss (\%) & \\
\hline POL0 & $71.45 \pm 0.09^{\mathrm{a}}$ & $13.10 \pm 0.14^{\mathrm{a}}$ & $279.73 \pm 0.03^{\mathrm{a}}$ & $46.96 \pm 0.04^{\mathrm{a}}$ & $39.02 \pm 0.04^{\mathrm{a}}$ \\
\hline P5L0 & $78.18 \pm 0.17^{\mathrm{a}}$ & $12.53 \pm 0.17^{\mathrm{a}}$ & $279.90 \pm 4.03^{\mathrm{a}}$ & $44.93 \pm 1.47^{\mathrm{a}}$ & $42.53 \pm 0.48^{\mathrm{a}}$ \\
\hline P10L0 & $71.05 \pm 0.20^{\mathrm{a}}$ & $9.42 \pm 0.06^{\mathrm{b}}$ & $280.10 \pm 1.42^{\mathrm{a}}$ & $47.33 \pm 0.70^{\mathrm{a}}$ & $43.19 \pm 0.36^{\mathrm{a}}$ \\
\hline P0L0.5 & $68.35 \pm 0.33^{\mathrm{b}}$ & $9.55 \pm 0.37^{\mathrm{b}}$ & $269.49 \pm 0.28^{\mathrm{b}}$ & $43.29 \pm 0.55^{\mathrm{a}}$ & $47.14 \pm 0.17^{\mathrm{a}}$ \\
\hline P5L0.5 & $64.25 \pm 0.31 \mathrm{~b}^{\mathrm{a}}$ & $9.92 \pm 0.88^{\mathrm{b}}$ & $267.37 \pm 0.56^{\mathrm{b}}$ & $44.75 \pm 0.40^{\mathrm{a}}$ & $45.32 \pm 0.57^{\mathrm{a}}$ \\
\hline P10L0.5 & $63.03 \pm 0.54^{\mathrm{b}}$ & $7.69 \pm 0.44^{\mathrm{b}}$ & $274.39 \pm 1.28^{\mathrm{b}}$ & $45.05 \pm 0.33^{\mathrm{a}}$ & $47.26 \pm 0.35^{\mathrm{a}}$ \\
\hline P0L1 & $67.52 \pm 0.50^{\mathrm{b}}$ & $8.33 \pm 0.39^{\mathrm{b}}$ & $266.45 \pm 0.49^{\mathrm{c}}$ & $42.40 \pm 2.24^{\mathrm{a}}$ & $49.27 \pm 0.48^{\mathrm{b}}$ \\
\hline P5L1 & $65.81 \pm 0.53^{\mathrm{b}}$ & $8.83 \pm 0.62^{\mathrm{b}}$ & $264.46 \pm 0.59^{\mathrm{c}}$ & $41.43 \pm 0.74^{\mathrm{a}}$ & $49.63 \pm 0.51^{\mathrm{b}}$ \\
\hline P10L1 & $63.14 \pm 0.46^{\mathrm{b}}$ & $6.85 \pm 0.59^{\mathrm{b}}$ & $264.48 \pm 0.65^{\mathrm{c}}$ & $41.84 \pm 0.65^{\mathrm{a}}$ & $51.31 \pm 0.41^{\mathrm{b}}$ \\
\hline
\end{tabular}

Values with different letters $(\mathrm{a}-\mathrm{c})$ within the same column differ significantly $(p<0.05)$

Mechanical Properties

The addition of lysozyme significantly influences on mechanical properties of edible coating. Observed lower TS and EB values resulted from increased lysozyme concentration (Table 3 and 4). The maximum TS value occurred for pure chitosan film (16.19 MPa). Film incorporating $0.5 \%$ lysozyme demonstrated about $25 \%$ lower TS value, and there were no significant differences between higher concentrations of enzyme. EB of films decreased from 9.69 without lysozyme to 8.08 and $6.65 \%$ when the lysozyme was added at 0.5 and $1.0 \%$. Similar relation between chitosan and lysozyme was reported by Park et al. (2004). Degradation ability of lysozyme against chitosan caused weakened film structure and reduced mechanical properties.

Results did not show significant variations for film exposed to helium plasma treatment. The dielectric barrier discharge operated at atmospheric plasma could be used to modify the surface properties of natural and synthetic fibres. El-Khatib et al. (2013) found out that oxygen plasma treatment slightly improves tensile strength and elongation at break of the wool/ polyester fibres. In contrast, low-pressure plasma treatment was unaffected or slightly reduced the tensile strength of the aramid fibre due to more aggressive etching process (Qiu et al. 2004).

Fig. 2 DMTA thermograms of chitosan films
Thermogravimetric Analysis

Table 5 shows the results of thermogravimetric analysis of chitosan-based films. All tested films have two degradation stages. The first stage starts at about $65-70{ }^{\circ} \mathrm{C}$ and can be assigned to water loss of film. The second one occurs at temperature range of about $265-280{ }^{\circ} \mathrm{C}$ and is accompanied by decomposition (thermal and oxidative) of chitosan, vapourization and elimination of volatile products. The result obtained for pure chitosan is in accordance with studies carried out by Rotta et al. (2011). Addition of lysozyme into films leads to decrease of about $15^{\circ} \mathrm{C}$ in the second thermal event. Enzymatic hydrolysis leads to chitosan degradation and results in lower molecular weight. Xie (2011) observed that complex enzymes composed of commercial cellulose, pectinase and $\alpha$-amylase degrade the large molecular chain of chitosan, and as a consequence, molecular weight lowered from 1,000,000 to 100,000. According to Tatro et al. (2003), lower thermal stability is caused by decreasing of molecular weight. The same result is observed in this study. Residue of weight increase about $10 \%$ when lysozyme was added at $1.0 \%$. The influence of helium plasma treatment on thermal stability was not observed. Yin et al. (2006) showed that addition of hydroxypropylmethylcellulose (HPMC) to chitosan increase the resistance to thermal

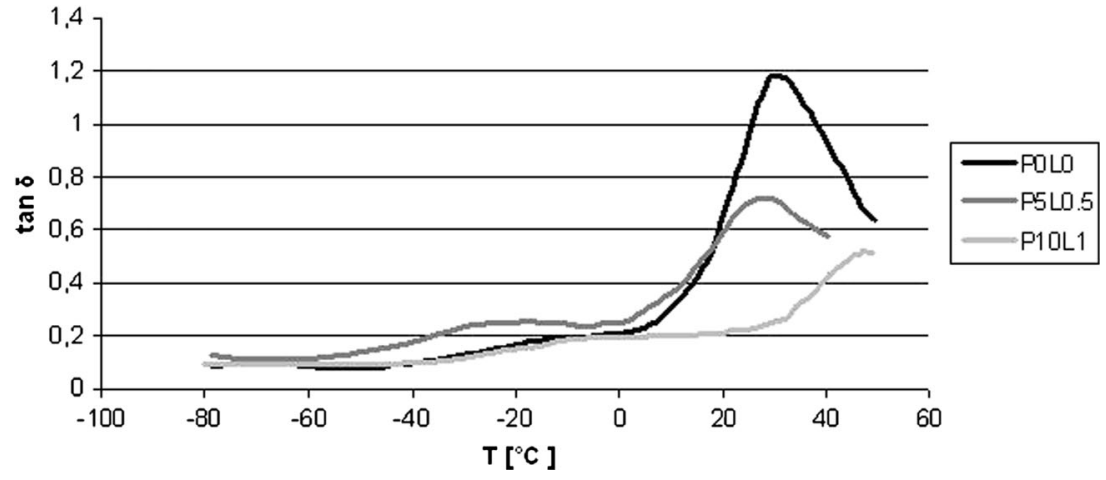


Fig. 3 Drop size of distilled water on the surface of chitosan films: P0L0 (a), P0L1 (b), P10L0 (c) and P10L1 (d)
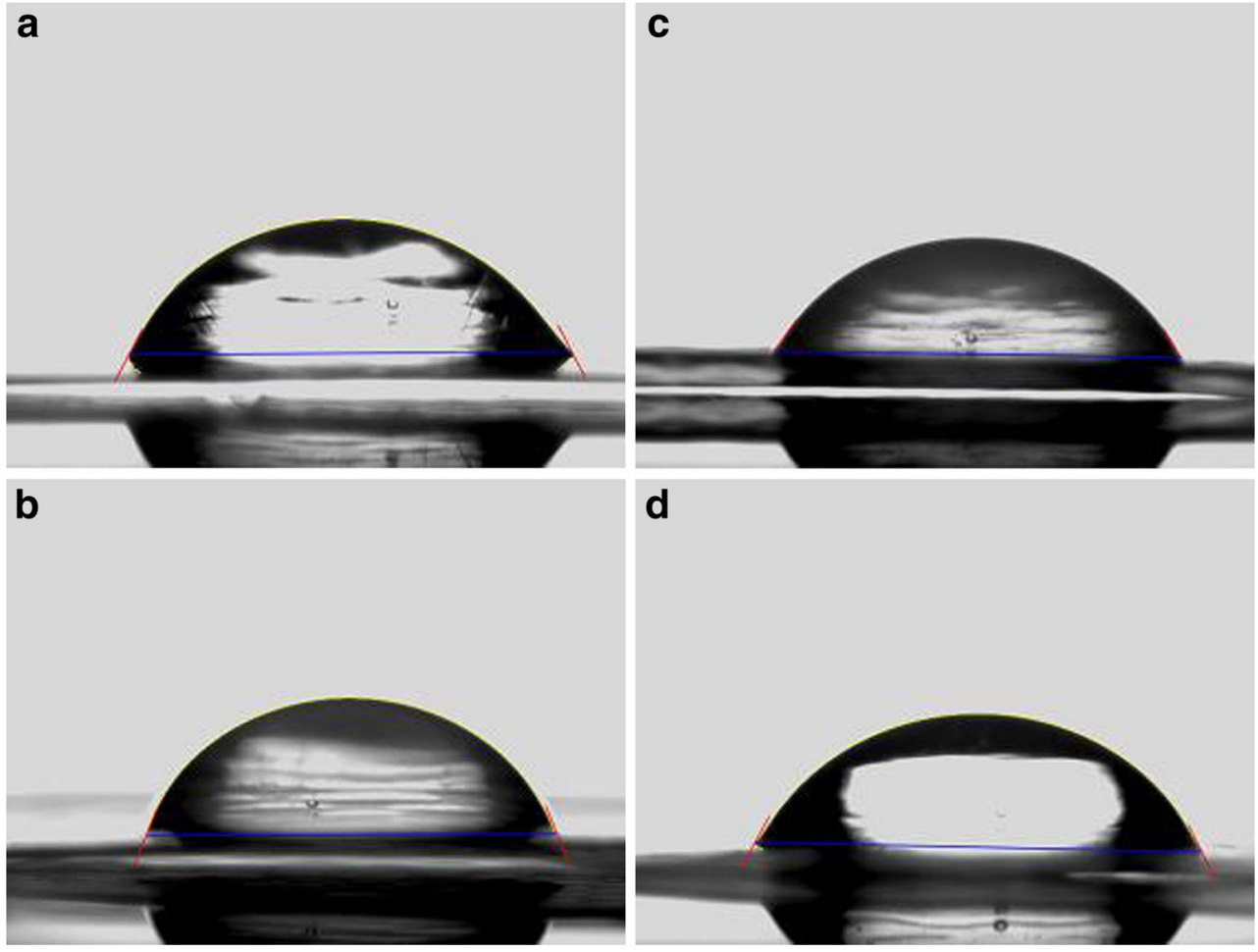

degradation. Thus, incorporation of HPMC into tested films should be considered.

\section{Dynamic Mechanical Thermal Analysis}

Chitosan films exhibit two tan $\delta$ peaks at positions around $-20-0{ }^{\circ} \mathrm{C}$ and $30-50{ }^{\circ} \mathrm{C}$. According to Mucha and Pawlak (2005), those peaks are attributed to relaxation processes. At a lower temperature, $\beta$-relaxation appears and has been assigned to the local side-chain movement of polysaccharides. The $\alpha$-relaxation is controlled by both intramolecular and intermolecular interactions. Toffey and Glasser (2001) noticed $\alpha$-relaxation between 60 and $94{ }^{\circ} \mathrm{C}$ for ionic complexes of chitosan. The temperatures of relaxations increase for amidized chitosan derivatives (Toffey and Glasser 2001). The main $\tan \delta$ peaks shift to a higher temperature as the lysozyme concentration increases (Fig. 2). Due to hydrolysis of chitosan, lower $\tan \delta$ values were observed. The $\tan \delta$ peak size is the reflection of the polymer in the composition of the analysed sample, what is confirmed by Wetton (1986).

\section{Contact Angle Measurements}

The contact angles of chitosan films are shown in Fig. 3. There were no significant differences between films with addition of lysozyme and exposed to helium plasma treatment. Contact

Table 6 Water vapour permeability for chitosan films

\begin{tabular}{|c|c|c|c|c|c|}
\hline \multicolumn{4}{|l|}{ Main effects } & \multicolumn{2}{|c|}{ Interaction effects } \\
\hline Plasma exposure (min) & WVP (g/s m Pa) & Lysozyme (\%) & WVP (g/s m Pa) & $\mathrm{P} \times \mathrm{L}$ & WVP (g/s m Pa) \\
\hline \multirow[t]{3}{*}{0} & \multirow[t]{3}{*}{$1.56 \pm 0.22 \mathrm{E}-10$} & \multirow[t]{3}{*}{0} & \multirow[t]{3}{*}{$1.34 \pm 0.25 \mathrm{E}-10$} & $0 \times 0$ & $1.54 \pm 0.31 \mathrm{E}-10$ \\
\hline & & & & $5 \times 0$ & $1.19 \pm 0.20 \mathrm{E}-10$ \\
\hline & & & & $10 \times 0$ & $1.28 \pm 0.08 \mathrm{E}-10$ \\
\hline \multirow[t]{3}{*}{5} & \multirow[t]{3}{*}{$1.33 \pm 0.32 \mathrm{E}-10$} & \multirow[t]{3}{*}{0.5} & \multirow[t]{3}{*}{$1.47 \pm 0.36 \mathrm{E}-10$} & $0 \times 0.5$ & $1.62 \pm 0.23 \mathrm{E}-10$ \\
\hline & & & & $5 \times 0.5$ & $1.53 \pm 0.43 \mathrm{E}-10$ \\
\hline & & & & $10 \times 0.5$ & $1.24 \pm 0.40 \mathrm{E}-10$ \\
\hline \multirow[t]{3}{*}{10} & \multirow[t]{3}{*}{$1.36 \pm 0.28 \mathrm{E}-10$} & \multirow[t]{3}{*}{1} & \multirow[t]{3}{*}{$1.45 \pm 0.24 \mathrm{E}-10$} & $0 \times 1$ & $1.49 \pm 0.17 \mathrm{E}-10$ \\
\hline & & & & $5 \times 1$ & $1.29 \pm 0.29 \mathrm{E}-10$ \\
\hline & & & & $10 \times 1$ & $1.64 \pm 0.04 \mathrm{E}-10$ \\
\hline
\end{tabular}

No significant $(p<0.05)$ differences between WVP values 

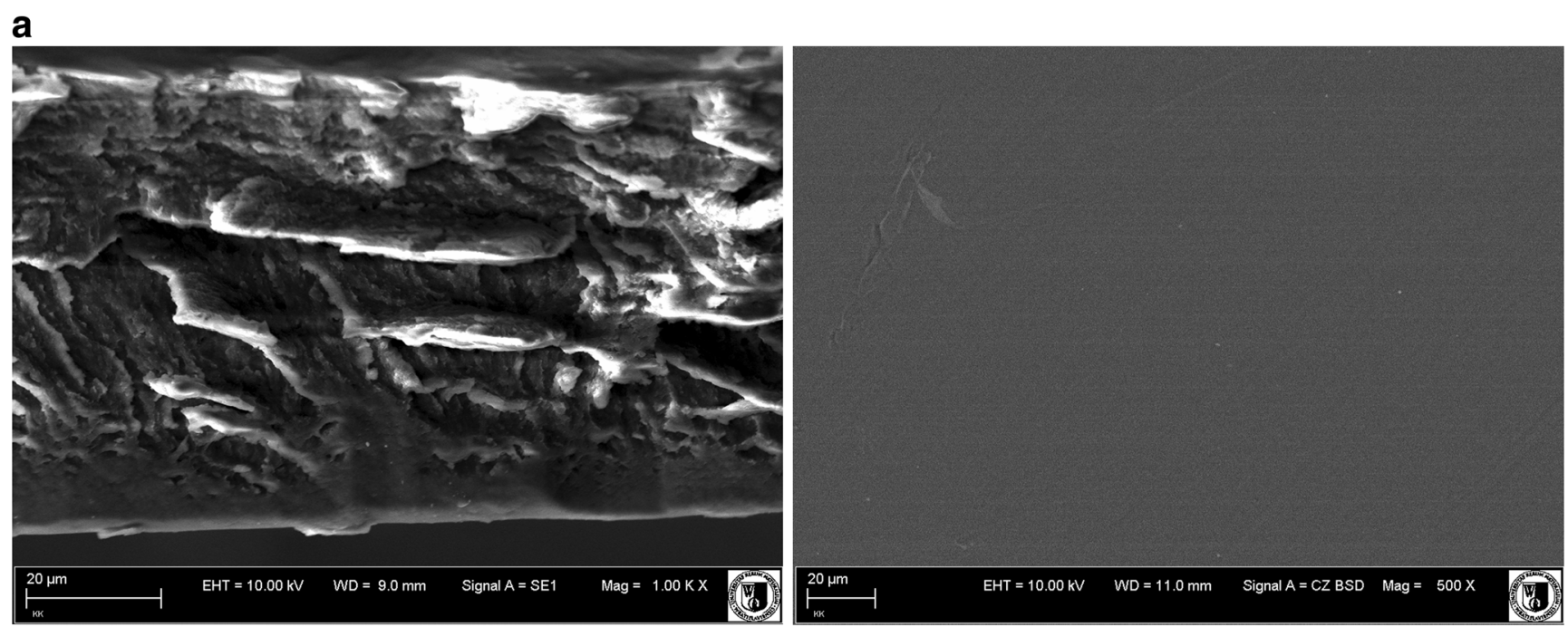

b
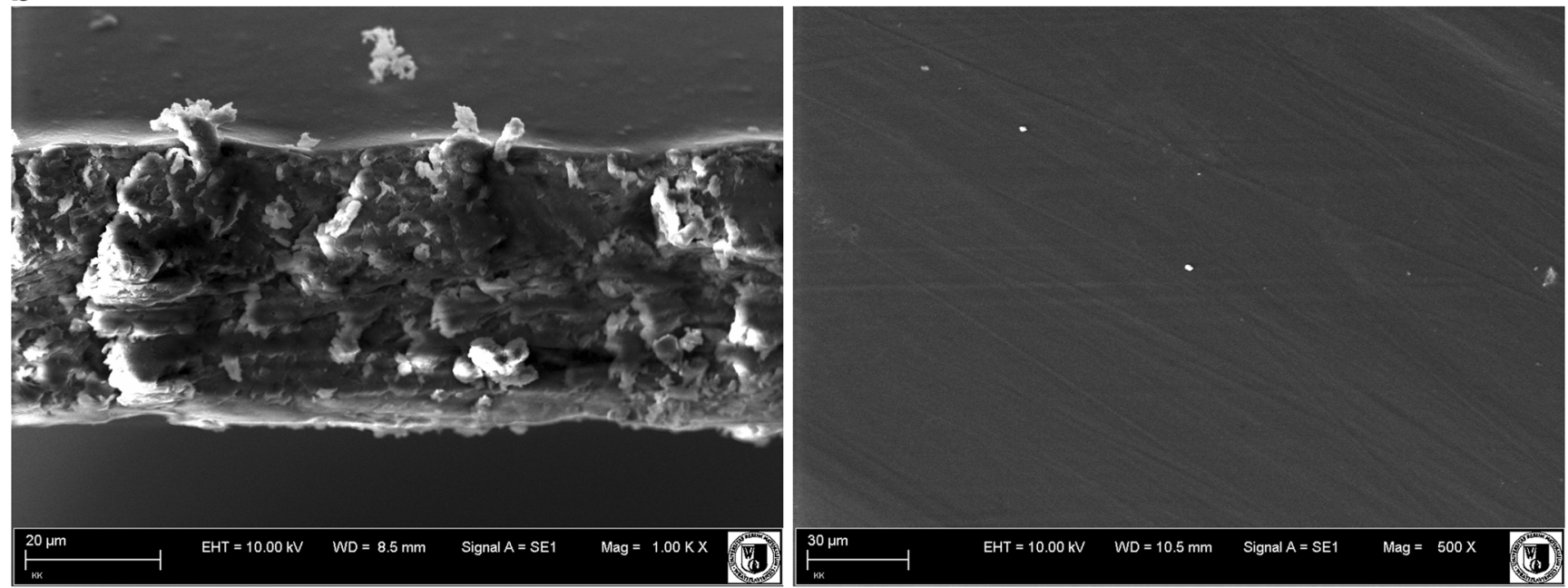

C
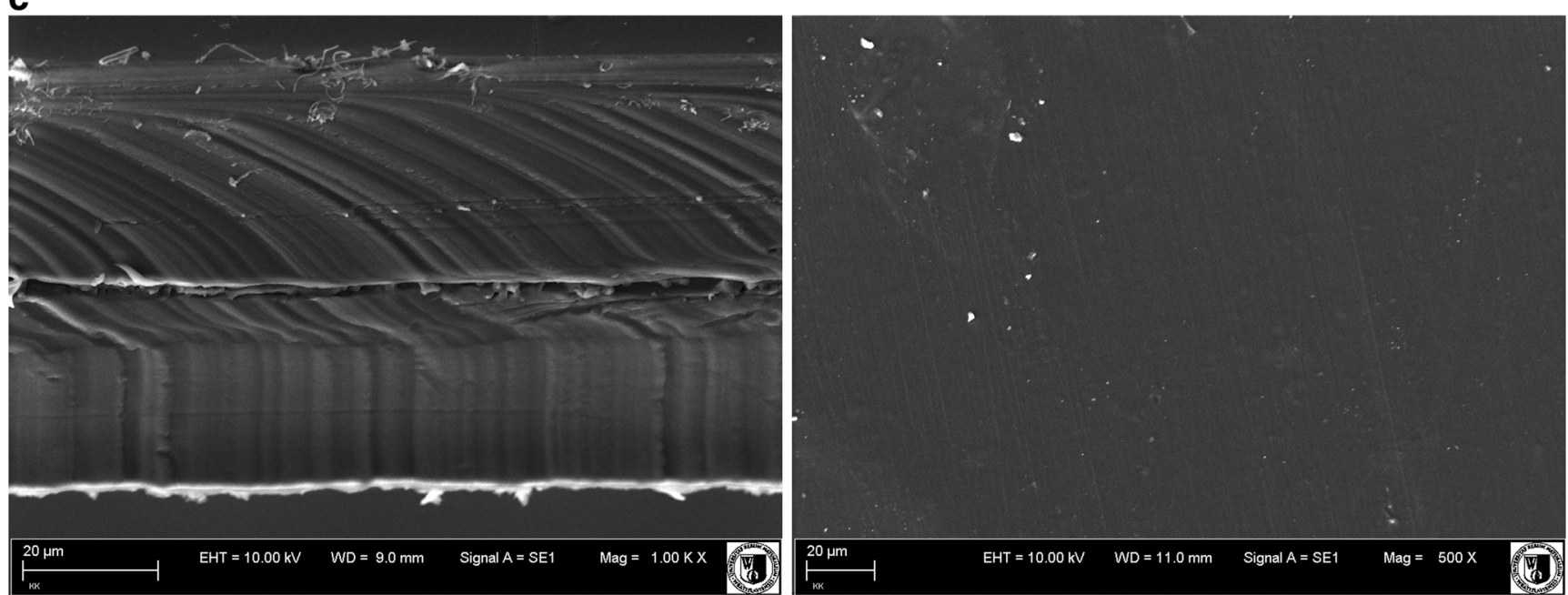

Fig. 4 SEM images of cross section (left) and surface (right) of chitosan films: P0L0 (a), P5L0.5 (b) and P10L1 (c)

angle below $90^{\circ}$ corresponds to hydrophilicity of surface, and more than $90^{\circ}$ corresponds to hydrophobicity of surface (Yuan and Lee 2013). Therefore, it can be assumed that the tested film indicates high wettability. Demina et al. (2012) found out that DC discharge plasma modification of chitosan, gelatin and poly(L,L-lactide) films caused a reduction in the contact 
angle of wettability. They observed the decrease in contact angle of film from initial value of 76 to $22 \%$ and $10 \%$ after plasma treatment on cathode and anode, respectively. An increase in the surface energy was also noticed. Those results reflected an increase of surface hydrophilicity. On the other hand, according to Park et al. (2004) hydrophilicity of lysozyme-chitosan film could decrease with addition of enzyme due to hydrophobic amino acid side chains in its structure. Those contradict effects could minimize the differences in contact angle.

\section{Water Vapour Permeability}

Water vapour permeability values of chitosan films are shown in Table 6. The WVP value varied from 1.19E-10 to 1.64E$10 \mathrm{~g} / \mathrm{s} \mathrm{m} \mathrm{Pa}$, but they were not significantly affected by either plasma exposure or lysozyme concentration. Similar results were obtained by Park et al. (2004). They also reported that WVP values were not affected by chitosan molecular weight (Park et al. 2002). On the other hand, water vapour barrier properties of the films depend on solvent acids being used. Chitosan films prepared with lactic acid showed slightly lower barrier properties compared to acetic acid. According to Leceta et al. (2013), the addition of 15 and $30 \%$ glycerol to chitosan films did not significantly influence on WVP values. Although incorporation of hydrophilic plasticizers into polysaccharide films could increase the WVP, due to low concentration of glycerol, no significant differences were observed. A relatively high water vapour permeability of chitosan film is caused by the hydrophilic nature of chitosan and glycerol. However, chitosan coatings could delay changes in weight loss of strawberries, banana and mango, and they are more effective than starch and cellulose derivatives (HernándezMuñoz et al. 2008).

\section{Scanning Electron Microscopy}

Study of the surface structure by SEM showed no significant differences in films exposed to helium plasma treatment compared to the untreated sample (Fig. 4). All films have homogenous structure without local destructions. Cross sections of chitosan film have rough structure and some cavities. The addition of lysozyme causes bright marbling on the film surface. The cross-section structures were compact and continuous when lysozyme was added. Similar effect of lysozyme was observed by Park et al. (2004). They reported that marbling increases with increasing lysozyme concentration. Cárdenas et al. (2010) observed some porosity on the chitosan lactate film generated by addition of glycerol and Tween 20 . According to Nadarajah (2005), the microstructure of chitosan films depends on the organic solvent being used. More homogeneous and continuous structure was observed for films formed with formic and citric acid than acetic acid.

\section{Conclusions}

The present study has proved the antibacterial activities of chitosan films. Inhibiting the growth of psychrotrophic bacteria effectively is particularly important in food industry, including meat production during carcass chilling. The higher antibacterial activity against $L$. monocytogenes and $P$. fluorescens is affected by the higher concentration of lysozyme. Although the addition of lysozyme caused reduction of mechanical properties of chitosan films, it could be used as the antibacterial agent incorporated in food packaging. Depending on the condition of cold plasma generation, various processes take place leading to surface modification or sterilization. This study is focussed on the decontamination process; thus, improvement of physical properties affected by low-pressure plasma was not expected. Besides taking into consideration costs of decontamination process by using cold plasma, short-term treatment is a must. Results also suggest that helium plasma does not influence on chemical structure of biocomponents, because they retain biological properties. The direct influence of combination of helium plasma treatment and edible chitosan films on meat microflora and its attributes will be investigated in the future. Both studied methods are universal and can find usage in a wide range of products as innovative system of food preservation.

Acknowledgments Authors thank for co-funding of the European Union through the European Regional Development Fund under the Operational Programme Innovative Economy, 2007-2013, the project 'Innovative technologies for the production of biopreparates based on the new generation eggs (OVOCURA)'. Authors would like to thank Marcin Zaród and Bartosz Głębocki from The Centre of Molecular and Macromolecular Studies Polish Academy of Sciences and Krzysztof Marycz from Department of Environment Hygiene and Animal Welfare Wrocław University of Environmental and Life Sciences for the assistance provided.

Open Access This article is distributed under the terms of the Creative Commons Attribution License which permits any use, distribution, and reproduction in any medium, provided the original author(s) and the source are credited.

\section{References}

ASTM D882 - 12 Standard test method for tensile properties of thin plastic sheeting.

ASTM E96 / E96M - 13 Standard test methods for water vapor transmission of materials.

Benhabiles, M. S., Salah, R., Lounici, H., Drouiche, N., Goosen, M. F. A., \& Mameri, N. (2012). Antibacterial activity of chitin, chitosan and its oligomers prepared from shrimp shell waste. Food Hydrocolloids, 29, 48-56.

Cárdenas, G., Anayaa, P., delRiob, R., Schrebler, R., Plessingc, C., \& Schneider, M. (2010). Scanning electron microscopy and atomic force microscopy of chitosan composite films. Journal of the Chilean Chemical Society, 55(3), 352-354. 
Cegielska-Radziejewska, R., Leśnierowski, G., \& Kijowski, J. (2008). Properties and application of egg white lysozyme and its modified preparations - a review. Polish Journal of Food and Nutrition Sciences. http://journal.pan.olsztyn.pl/fd.php?f=930. Accessed 05 May 2014.

Chung, Y. C., Su, Y. P., Chen, C. C., Jia, G., Wang, H. L., Wu, J. C. G., \& Lin, J. G. (2004). Relationship between antibacterial activity of chitosan and surface characteristics of cell wall. Acta Pharmacologica Sinica, 25(7), 932-936.

Demina, T., Zaytseva-Zotova, D., Yablokov, M., Gilman, A., Akopova, T., Markvicheva, E., \& Zelenetskii, A. (2012). DC discharge plasma modification of chitosan/gelatin/PLLA films: surface properties, chemical structure and cell affinity. Surface \& Coatings Technology, 207, 508-516.

Dutta, P. K., Dutta, J., \& Tripathi, V. S. (2004). Chitin and chitosan: chemistry, properties and applications. Journal of Scientific \& Industrial Research. http://nopr.niscair.res.in/bitstream/123456789/ 5397/1/JSIR\%2063\%281\%29\%2020-31.pdf. Accessed 05 May 2014.

El-Khatib, E. M., Raslan, W. M., El-Halwagy, A. A., \&Galab, S. (2013). Effect of low temperature plasma treatment on the properties of wool/polyester blend. Research Journal of Textile and Apparel. http://rjta.org/download.php?paper=1\&paper_id=13_1_ 13\&PHPSESSID $=19 \mathrm{e} 0 \mathrm{f} 7 \mathrm{~d} 09 \mathrm{f} 970660 \mathrm{~d} 10 \mathrm{fa} 98 \mathrm{~b} 01 \mathrm{eff0} 1 \overline{\mathrm{la}}$. Accessed 05 May 2014.

Elsabee, M. Z., \& Abdou, E. S. (2013). Chitosan based edible films and coatings: a review. Materials Science and Engineering C, 33, 18191841.

Hernández-Muñoz, P., Almenar, E., Del Valle, V., Velez, D., \& Gavara, R. (2008). Effect of chitosan coating combined with postharvest calcium treatment on strawberry (Fragaria $\mathrm{x}$ ananassa) quality during refrigerated storage. Food Chemistry, 110, 428-435.

Hughey, V. L., \& Johnson, E. A. (1987). Antimicrobial activity of lysozyme against bacteria involved in food spoilage and foodborne disease. Applied and Environmental Microbiology, 53(9), $2165-2170$

Leceta, I., Guerrero, P., \& Caba, K. (2013). Functional properties of chitosan-based films. Carbohydrate Polymers, 93, 339-346.

Leistner, L., \& Gould, G. W. (2002). Hurdle technologies: combination treatments for food stability, safety and quality. New York: Plenum Publishers.

Miller, J., \& Haden, P. (2006). Statistical analysis with general linear model. https://docs.google.com/file/d/0B1fyuTuvj3YoaFdUR3FZaXNuNXc/ edit. Accessed 05 May 2014.

Moisan, M., Barbeau, J., Crevier, M. C., Pelletier, J., Philip, N., \&Saoudi, B. (2002). Plasma sterilization. Methods and mechanisms. Pure and Applied Chemistry. http://ta.mui.ac.ir/images/stories/10.pdf. Accessed 05 May 2014.

Moreira, M. d. R., Pereda, M., Marcovich, N. E., \& Roura, S. I. (2011). Antimicrobial effectiveness of bioactive packaging materials from edible chitosan and casein polymers: assessment on carrot, cheese and salami. Journal of Food Science, 76(1), 1054-1063.

Mucha, M., \& Pawlak, A. (2005). Thermal analysis of chitosan and its blends. Thermochimica Acta, 427, 69-76.
Nadarajah, K. (2005) Development and characterization of antimicrobial edible films from crawfish chitosan. $\mathrm{PhD}$, Baton Rouge, LA: Louisiana State University.

Park, S. I., Daeschel, M. A., \& Zhao, Y. (2004). Functional properties of antimicrobial lysozyme-chitosan composite films. Journal of Food Science, 69(8), 1215-1221.

Park, S. Y., Marsh, K. S., \& Rhim, J. W. (2002). Characteristics of different molecular weight chitosan films affected by the type of organic solvents. Journal of Food Science, 67(1), 194-197.

Qiu, Y., Shao, X., Jensen, C., Hwang, Y. J., Zhang, C., \& Mccord, M. G. (2004). The effects of atmospheric pressure plasma treatments on adhesion and mechanical properties pf high-performance fibers for composites. In K. L. Mittal (Ed.), Polymer surface modification: relevance to adhesion (Vol. 3, pp. 3-14). Boca-Raton: CRC Press.

Rotta, J., Minatti, E., \& Baretto, P. L. M. (2011). Determination of structural and mechanical properties, diffractometry, and thermal analysis of chitosan and hydroxypropylmethylcellulose (HPMC) films plasticized with sorbitol. Ciência e Tecnologia de Alimentos, $31(2), 450-455$.

Salazar, O., \& Asenjo, J. A. (2007). Enzymatic lysis of microbial cells. Biotechnology Letters, 29(7), 985-994.

Skurtys, O., Acevedo, C., Pedreshi, F., Enrione, J., Osorio, F., \& Aguilera, J. M. (2010). Food hydrocolloid edible films and coatings. New York: Nova Science Publishers Inc.

Sofos, J. N. (1994). Microbial growth and its control in meat, poultry and fish. In A. M. Pearson \& T. R. Dutson (Eds.), Quality attributes and their measurement in meat, poultry nad fish products (pp. 359-391). London: Blackie Academic \& Profession.

Tatro, S. R., Baker, G. R., Bisht, K., \& Harmon, J. P. (2003). A MALDI, TGA, TG/MS, and DEA study of the irradiation effects on PMMA. Polymer, 44, 167-176.

Toffey, A., \& Glasser, W. G. (2001). Chitin derivatives III formation of amidized homologs of chitosan. Cellulose, 8, 35-47.

Ulbin-Figlewicz, N., Brychcy, E., \& Jarmoluk, A. (2013). Effect of lowpressure cold plasma on surface microflora of meat and quality attributes. Journal of Food Science and Technology. doi:10.1007/ s13197-013-1108-6.

Wetton, R. E. (1986). Dynamic mechanical thermal analysis of polymers and related systems. In J. V. Dawkins (Ed.), Developments in polymer characterization (pp. 179-222). New York: Springer.

Xie, H. (2011). Preparation of low molecular weight chitosan by complex enzymeshydrolysis. International Journal of Chemistry, 3(2), 180-186.

Ye, M., Neetoo, H., \& Chen, H. (2008). Control of Listeria monocytogenes on ham steaks by antimicrobials incorporated into chitosan-coated plastic films. Food Microbiology, 25(2), 260-268.

Yin, J., Luo, K., Chen, X., \& Khutoryanski, V. V. (2006). Miscibility studies of the blends of chitosan with some cellulose ethers. Carbohydrate Polymers, 63(2), 238-144.

Yuan, Y., \& Lee, T. R. (2013). Contact angle and wetting properties. In G. Bracco \& B. Holst (Eds.), Surface science techniques (pp. 3-34). Berlin: Springer.

Yuceer, M., \& Caner, C. (2013). Antimicrobial lysozyme-chitosan coatings affect functional properties and shelf life of chicken eggs during storage. Journal of the Science of Food and Agriculture, 94, 153-162. 